Ю. Швець,

кандидат економічних наук, доцент, докторант

Львівського університету бізнесу та права

\title{
АДМІНІСТРАТИВНО-ПРАВОВІ ОСНОВИ ЗАХИСТУ ЛІКАРСЬКОЇ ТАЕМНИЦІ: ДОСВІД ЕВРОПЕЙСЬКИХ КРАЇН ТА ПЕРСПЕКТИВИ ДЛЯ УКРАЇНИ
}

Постановка проблеми. До найважливіших завдань сучасної держави належать охорона життя і здоров’я людини та громадянина, а також забезпечення недоторканності приватного життя. Одним 3 інститутів, який покликаний захищати відповідні законні права та інтереси, є інститут лікарської таємниці, адже саме завдяки їй забезпечується дотримання конфіденційності в сфері охорони здоров'я.

Правило конфіденційності покликане вберегти лікаря і пацієнта від несанкціонованого ними «вторгнення ззовні» в приватне життя особи і сам процес лікування. За цим інформація про пацієнта, яку лікар отримує з його вуст або внаслідок обстеження, не може передаватися третім особам без дозволу пацієнта. Це правило зафіксоване як лікарська таємниця в багатьох моральних кодексах, починаючи з клятви Гіппократа. Стосується воно не тільки лікарів, а й усіх медичних працівників, які мають доступ до медичної інформації.

Аналіз досліджень і публікацій свідчить про те, що серед учених, роботи яких присвячені проблемам правового регулювання інституту лікарської таємниці, також можна виділити Ю. Аргунову, В. Головченко, Л. Дембо, Н. Коробцову, О. Махнік,
С. Стеценко, Ж. Чевічалову, І. Шатковську та ін. Разом із тим слід констатувати, що порівняльні аспекти функціонування інституту лікарської таємниці поки досліджені недостатньо.

Метою статті $€$ дослідження законодавства зарубіжних країн, що регламентує забезпечення конфіденційності у сфері охорони здоров'я, у тому числі в порівняльному аспекті.

Виклад основного матеріалу. Лікарська таємниця належить до одного 3 видів професійної таємниці й $€$ самостійним видом інформації з обмеженим доступом, який відносять як до конфіденційної інформаціï, так і до охоронюваної законом секретної інформації, яка не становить державну таємницю. Виділення лікарської таємниці в самостійну групу сприяє встановленню єдиного правового режиму охорони відомостей, їі складників, який не тотожний жодному іншому правовому режиму інформації з обмеженим доступом.

Предметом лікарської таємниці, як правило, є дані про стан здоров'я пацієнта, діагноз, прогноз розвитку хвороби й усі відомості, що стали доступними лікарю в результаті обстеження або зі слів пацієнта. Законодавство визначає вузьке коло ситуацій, в яких медичний працівник має право 
передати відому йому медичну інформацію третім особам, зокрема у разі якщо пацієнт не здатний самостійно висловити свою волю, за наявності загрози поширення інфекційних захворювань, масових отруєнь тощо.

Як відзначав сучасний англійський учений, фахівець із медичної етики Р. Едвардс, існує сім основних чинників, що забезпечують істотне значення конфіденційності в багатьох сферах професійної діяльності, особливо в медицині [1; 2]: конфіденційність у відносинах між професіоналом і клієнтом (лікарем і пацієнтом). Гарантія безумовного дотримання лікарем вимог конфіденційності стимулює пацієнта до відвертості, і він не повинен побоюватися, що недоторканність його приватного життя може бути порушена; правило конфіденційності є умовою захисту соціального статусу пацієнта, оскільки медичний діагноз чи інша медична інформація можуть стати клеймом для людини, що значно обмежить можливості його соціального самоствердження; правило конфіденційності захищає економічні інтереси пацієнта; конфіденційність необхідна для забезпечення відкритості в спілкуванні лікаря і пацієнта; від здатності лікарів забезпечувати конфіденційність інформації про своїх пацієнтів залежать їх популярність і престиж; ефективно реалізуючи вимогу конфіденційності, лікарі забезпечують довіру у відносинах із пацієнтами, яке за своєю суттю є більш важливим, аніж відвертість. Нерідко важко хвора людина повністю залежить від лікарів, тому вона має довіряти їм і вірити, що вони завжди будуть керуватися його інтересами [2].

Орієнтиром для національного законодавства з питань забезпечення конфіденційності інформації про здоров'я, охорони здоров'я та функціонування інституту лікарської таємниці $€$ міжнародні нормативно-правові акти у цій сфері. Так, ст. 17 Міжнародного пакту про громадянські i політичні права передбачає, що ніхто не повинен зазнавати свавільного чи незаконного втручання в його особисте і сімейне життя, свавільних чи незаконних посягань на недоторканність його житла, таємницю його кореспонденції, незаконних посягань на його честь і репутацію [3].

Ст. 6 Європейської хартії прав пацієнтів передбачає, що кожен має право на конфіденційність особистої інформації, включаючи інформацію про стан здоров'я і можливі діагностичні або терапевтичні процедури, а також на захист своєї приватності під час проведення діагностичних оглядів [4].

Згідно зі ст. 8 Хартії про право на здоров'я, лікарі зв'язані необхідністю дотримання професійного правила конфіденційності (лікарської таємниці), яка забезпечує повагу до приватного життя їхніх пацієнтів і сприяє ефективності надання медичної допомоги. Винятки 3 правила лікарської таємниці повинні бути чітко обмежені законом і можуть бути виправдані суто метою охорони здоров'я, безпеки або забезпечення санітарно-гігієнічних умов у суспільстві. Пацієнти не пов'язані правилом лікарської таємниці. Лікарі можуть бути звільнені від обов'язку зберігати лікарську таємницю, якщо їм стає відомо про посягання на людську гідність [5].

«Право на конфіденційність» - це також принцип 8 Лісабонської декларації про права пацієнта. За змістом цього принципу вся інформація, за якою ідентифікуються стан здоров'я пацієнта, захворювання, діагноз, прогноз і лікування, а також будь-яка інша особиста інформація розглядатимуться як конфіденційна навіть після смерті пацієнта. У надзвичайних випадках родичі по низхідній лінії можуть отримати право доступу до інформації, що стосується ризику спадкових захворювань. Конфіденційна інформація може розголошуватися тільки в тому разі, якщо пацієнт дасть безпосередню згоду або таке

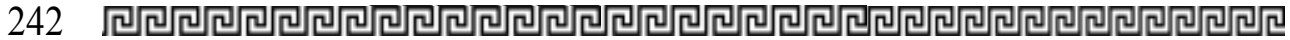


розголошення прямо передбачено законом. Якщо пацієнт явно не дав прямої згоди на розкриття відомостей, інформацію можуть повідомляти іншим особам, які надають медичну допомогу, виключно в разі потреби. Усі ідентифікаційні відомості про пацієнта повинні зберігатися і забезпечуватися захистом, так само як i субстанції людського організму, які можуть бути джерелом ідентифікаційних відомостей [6].

Ч. 1 ст. 8 Європейської конвенції про захист прав людини і основних свобод (ЕКЗПЛОС) установлює, що кожен має право на повагу до свого приватного і сімейного життя, до свого житла і кореспонденції [7]. У зв'язку із цим Європейський суд з прав людини (ЄСПЛ) ухвалив, що «захист особистих даних - не в останню чергу медичних даних - має фундаментальне значення для реалізації людиною іï права на повагу до приватного і сімейного життя... Повага до конфіденційності відомостей про здоров'я людини - найважливіший принцип правових систем - учасниць ЕКЗПЛОС... Необхідно не тільки поважати приватність пацієнта, а й підтримувати в ньому довіру до представників медичної професії і до медичних служб у цілому» [8]. Також ЄСПЛ зазначає, що розкриття медичних відомостей «може суттєво вплинути на приватне та сімейне життя людини, на його суспільне становище і зайнятість, піддавши його громадському засудженню i ризику остракізму» [9]. У Рішенні ЄСПЛ у справі «I. Ф. проти Туреччини» $(24209 / 94)$ відзначається, що тіло людини належить до інтимних аспектів його приватного життя, тому існує чіткий зв'язок між правом на приватність і правом на фізичну недоторканність [10]. Згідно 3 ч. 1 ст. 10 Конвенції про права людини та біомедицину, кожен має право на повагу до свого приватного життя стосовно інформації про його здоров'я [11]. Ч. 1 ст. Рекомендацій № R (2004) 10 Ради Європи передба- чає, що всі персональні дані особи, яка страждає на психічне захворювання, повинні вважатися конфіденційними. Збір, обробка та передача таких даних повинні проводитися відповідно до правил, які стосуються дотримання професійної таємниці і збору персональних даних [12].

За змістом ч. 1, ч. 8 ст. 4 Декларації про політику в галузі дотримання прав пацієнта в Європі вся інформація про стан здоров'я пацієнта повинна залишатися конфіденційною навіть після смерті пацієнта. Пацієнти, що надходять до лікувально-профілактичного закладу, мають право розраховувати на наявність у цьому закладі матеріальних умов, необхідних для гарантування збереження лікарської таємниці [13].

Конвенція про захист осіб у зв'язку з автоматичною обробкою персональних даних уводить додаткові гарантії захисту приватного життя у зв'язку 3 обробкою персональних даних (тобто гарантії захисту персональних даних). Так, до даних висуваються такі вимоги: персональні дані, що проходять автоматичну обробку, повинні бути сумлінно і законно отримані й оброблені; повинні накопичуватися для точно визначених i законних цілей та не використовуватися в розбіжності із цими цілями; повинні бути адекватними, стосуватися справи і не бути зайвими щодо цілей, для яких вони накопичуються; повинні бути точними і в разі необхідності оновлюватися; повинні зберігатися в такій формі, яка дає змогу ідентифікувати суб'єктів даних не довше, ніж цього вимагає мета, для якої ці дані накопичуються (ст. 5). Відповідно до ст. 6, персональні дані, що стосуються здоров'я, можуть піддаватися автоматичній обробці тільки в тому разі, коли національне право передбачає належні гарантії ї захисту [14].

Водночас у Резолюціі Парламентської Асамблеї Ради Європи № 1165 (1998) зазначено, що публічні особи повинні усвідомлювати, 
що особливий статус, який вони мають у суспільстві, автоматично збільшує рівень тиску на приватність іхнього життя [15]. Тому перебування особи на посаді, пов'язаній зі здійсненням функцій держави або органів місцевого самоврядування, передбачає не тільки гарантії захисту прав цієї особи, а й додаткові правові обтяження, у тому числі у сфері дотримання конфіденційності інформації про здоров'я. У рішенні Von Hannover v. Germany ЄСПЛ указує: відмінності, встановлені між видатними постатями сучасності i «щодо публічними особами», повинні бути чіткими й очевидними, щоб у державі, де дотримується принцип верховенства права, конкретна особа мала конкретні вказівки щодо того, як себе потрібно вести. Перш за все такі особи повинні обов'язково знати, де і коли вони захищені, а де й коли, навпаки, можливе втручання інших осіб (п. 73) [16]. Відповідно, під час установлення балансу на національному рівні необхідно бути вкрай обережним, визначаючи суб'єкта дійсно тією посадовою особою, медична інформація про яку становить загальний інтерес [17].

Переходячи до розгляду національної специфіки законодавчого забезпечення конфіденційності, слід зазначити, що в Німеччині до медичного законодавства як на федеральному рівні, так і на рівні окремих земель відносяться норми, що регулюють: заходи проти особливо небезпечних інфекцій; допуск до медичної діяльності; обіг лікарських засобів i наркотичних лікарських препаратів тощо [18, с. 51-52]. Аналізуючи історію німецького законодавства про лікарську таємницю, О. Махнік зазначає, що «німецьке законодавство забороняло лікарям повідомляти довірені їм відомості під час виконання професійних обов'язків. Якщо лікар запрошений як свідок, то йому надається право відмовитися від дачі показань, якщо пацієнт, якого він лікував, не дав йому на це дозволу» [19, с. 126]. Сьогодні, згідно з $§ 53$ Кримінального процесуального кодексу ФРН, не допускається допит як свідків осіб, яким закон надає право відмови від дачі показань як свідків. Таким правом, зокрема, користуються лікарі, стоматологи, аптекарі, акушери [20]. Зауважимо, що після катастрофи літака Germanwings, в якій загинули 150 осіб, у Німеччині йшло активне громадське обговорення щодо можливості пом'якшення правила про нерозголошення лікарської таємниці, зокрема по відношенню до представників професій, пов'язаних із ризиком. Водночас голова федерального об'єднання психотерапевтів Р. Ріхтер виступив проти пом'якшення зобов'язань щодо нерозголошення даних про пацієнтів, адже лікарі та психотерапевти і без цього мають право відступати від цього принципу, якщо тим самим вони можуть запобігти збитку третім особам [21].

Аналогічно у ст. 378 Кримінального кодексу Франції передбачено кримінальну відповідальність за розголошення лікарями та іншими співробітниками охорони здоров'я лікарської таємниці за винятком випадків, коли закон дозволяє або зобов'язує розголошувати іï [20].

Висновки. Підсумовуючи, слід зазначити, що загальним трендом національного законодавства багатьох країн є встановлення балансу між правилом конфіденційності щодо інформації про стан здоров'я пацієнта і заходи з охорони здоров'я і безпекою власне пацієнта і третіх осіб.

Також розвиток Інтернету речей, який першочергово торкається медицини, визначає перегляд багатьох національних та міжнародних стандартів. На цьому наголошує низка науковців [21].

Проблеми з безпекою і конфіденційність - одні з головних перешкод на шляху розвитку ІоТ. Зважаючи на це та відповідно до основних вимог стандарту TS 103 645, пропонується роз-

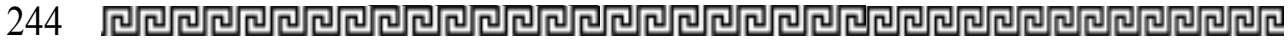


робникам IоT у сфері медицини: відмовитися від універсальних паролів, які часто стають причиною проблем із кібербезпекою; оприлюднювати всі дані про виявлені вразливості з метою інформування всіх зацікавлених компаній для вдосконалення власних систем у процесі надання медичних послуг; перевіряти дані, що надходять із призначеного для користувача інтерфейсу і передаються через API або зовнішні мережі, на предмет уразливості 3 метою запобігання злому умислу і викраденню даних зловмисниками; IоT у сфері медицини мають відповідати Загальному регламенту про захист даних (GDPR).

Основна мета розвитку IоT у медицині - це отримання максимально повної інформації про організм людини, на підставі якої можна приймати обгрунтовані рішення, що запобігають виникненню і розвитку захворювань. При цьому пріоритетом має залишатися безпека людини. А тому питання кібербезпеки залишаються і надалі мають бути пріоритетними під час розроблення ІоТ, адже сьогодні жоден виробник IоT не може надати гарантії щодо викрадення медичних даних чи внесення в них змін.

Ключові орієнтири, які, на нашу думку, обов'язково повинні враховуватися під час подальшого вдосконалення національного законодавства щодо забезпечення конфіденційності інформації у сфері охорони здоров'я, - це пріоритетність прав, свобод і законних інтересів особи в поєднанні зі спробою зробити охорону здоров'я громадян, медичну сферу у цілому високоякісною, високотехнологічною та відповідною найкращим світовим практикам і вимогам міжнародних нормативно-правових актів у відповідній сфері.

У статті зроблено висновок про те, щзо загальним трендом національного законодавства багатьох країн е встановлення балансу між правилом конфіденційності щодо інформації про стан здоров'я пацієнта i заходи з охорони здоров'я $i$ безпекою власне пацієнта та третіх осіб. Визначено ключові орієнтири, які обов'язково повинні враховуватися під час подальшого вдосконалення національного законодавства щодо забезпечення конфіденційності інформаціі у сфері охорони здоров'я, - ие пріоритетність прав, свобод $i$ законних інтересів особи у поєднанні зі спробою зробити охорону здоров'я громадян, медичну сферу у ијлому високоякісною, високотехнологічною та відповідною найкращим світовим практикам $i$ вимогам міжнародних нормативноправових актів у відповідній сфері.

Лікарська таємниия належить до одного з видів професійної таємниці $i$ є самостійним видом інформації $з$ обмеженим доступом, який відносять як до конфіденизйної інформації, так i до охоронюваної законом секретної інформації, яка не становить державну таємницю. Виділення лікарської таємниці в самостійну групу сприяе встановленню єдиного правового режиму охорони відомостей, iï складників, який не тотожний жодному іншому правовому режиму інформації з обмеженим доступом.

Ключові орієнтири, які, на нашу думку, обов'язково повинні враховуватися під час подальшого вдосконалення національного законодавства щодо забезпечення конфіденційності інформації у сфері охорони здоров'я, - це пріоpumemнicms прав, свобод $i$ законних інтересів особи у поєднанні зі спробою зробити охорону здоров'я громадян, медичну сферу у иілому високоякісною, високотехнологічною та відповідною найкращим світовим практикам $і$ вимогам міжнародних нормативно-правових актів у відповідній сфері.

Ключові слова: адміністративно-правові основи, лікарська таємниця, конфіденційна інформація, захист прав пацієнта. 
Shvets Yu. Administrative and legal basis for the protection of medical secrets: the experience of European countries and prospects for Ukraine

The article concludes that the general trend in the national legislation of many countries is to strike a balance between the rule of confidentiality of information about the patient's health and health measures, as well as the safety of the patient and third parties. The key guidelines that must be taken into account in the further improvement of national legislation to ensure the confidentiality of information in the field of health - the priority of rights, freedoms and legitimate interests of the individual in combination with the attempt to make public health, the health sector as a whole high-quality, high-tech and in line with the best world practices and requirements of international regulations in the relevant field.

Medical secrecy refers to one of the types of professional secrecy and is an independent type of information with limited access, which is classified as confidential information and classified information protected by law, which is not a state secret. The allocation of medical secrecy in an independent group contributes to the establishment of a single legal regime for the protection of information, its components, which is not identical to any other legal regime of information with limited access.

The key guidelines, which, in our opinion, must be taken into account in the further improvement of national legislation to ensure the confidentiality of information in the field of health - is the priority of rights, freedoms and legitimate interests of the individual combined with the attempt to protect public health, medical sphere as a whole of high-quality, high-tech and corresponding to the best world practices and requirements of the international regulatory legal acts in the corresponding sphere.

Key words: administrative and legal bases, medical secrecy, confidential information, protection of patients' rights.

\section{Література}

1. Биомедицинская этика и коммуникации в здравоохранении: учебно-методическое пособие / А.T. Щастный и др. ; под ред. А.Т. Щастного. Витебск : ВГМУ, 2018. $310 \mathrm{c}$.

2. Правило конфіденциальности. URL: https://dt.ua/HEALTH/likarskatayemnicya-ta-bezpeka-suspilstva-_html.

3. Международныци пакт о гражданских и политических правах (принят резолюиией 2200 A (ХХI) Генеральной Ассамблеи от 16.12.1966). URL: https:/ / www.un.org/ru/documents/decl_conv/ conventions / pactpol.shtml.

4. Европейская хартия прав пациентов. URL: http: / / health-rights.org / index.php/cop/item / \% D $0 \%$ B $5 \%$ D $0 \%$ $B 2 \%$ D $1 \% 80 \%$ DO $\%$ BE 0 DO $\%$ BF\% DO\% $B 5 \%$ D $0 \%$ B $9 \%$ D $1 \% 81 \%$ D $0 \%$ B A \%

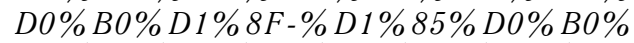
$D 1 \% 80 \%$ D $1 \% 82 \%$ D $0 \%$ B $8 \%$ D $1 \% 8 F$ $\%$ D0\% BF\% D $1 \% 80 \%$ DO $\%$ BO $\%$ DO $\%$ B2$\%$ DO $\%$ BF $\%$ DO $\%$ BO $\%$ D $1 \% 86 \%$ D $0 \%$ B $8 \%$ $D 0 \% B 5 \%$ DO $\%$ BD $\%$ D $1 \% 82 \%$ D0\% BE\% D $0 \% B 2-2$.

5. Хартия о праве на здоровье. Международный союз юристов. 31.08.2005. URL: wrw.uianet.org / documents / qquia / resolutions / Sante4GB.pdf.

6. Лиссабонская декларащия о правах пациента (принята 34-й Всемирной медицинской ассамблеей. Лиссабон, Португалия, сентябрь-октябрь 1981 года (с учетом изменений и дополнений, внесенных 47-й Генеральной Ассамблеей. Бали, Индонезия, сентябрь 1995 г.). URL: http://wrere-stomatology.ru/star/info/ 2010/lissabon_declaration.htm.

7. Конвенция о защите прав человека и основных свобод (измененная и дополненная Протоколом № 11 в сопровождении текстов протоколов №№ 1,4$),$ г. Рим, 04.11.1950. URL: https://old.irs.in.ua/ index.php?option $=$ com_\% 20content\&view $=$ article\&id $=276 \% 3$ A1\& catid $=43 \% 3$ Aeu\&Ite mid $=70 \&$ lang $=r u$.

8. Рішенняусправі «M.С.протиШвеції (27/08/1997) / Рішення Європейського 
суду з прав людини щодо доступу до інформаціï. URL: https://rm.coe.int/ CoERMPublic CommonSearchServices / Dis playDCTMContent documentId $=090000168$ 044e84d.

9. Рішення у справі «Z проти Фінляндіï» (25 EHRR 371) / Рішення Європейського суду з прав людини щодо доступу до інформаціï. URL: https:// rm.coe.int/ CoERMPublic CommonSearchServices / Disp layDCTMContent?document Id $=0900001680$ $44 e 84 d$.

10. ЕСПЛ. Рішення у справі «I.Ф. проти Туреччини» (24209/94) / Рішення Європейського суду з прав людини щодо доступу до інформаціï. URL: https://rm.coe.int/ CoERMPublic CommonSearchServices / Displ ayDCTMContent?documentId $=09000016804$ $4 e 84 d$.

11. Конвениия о правах человека и биомедицине. URL: https://rm.coe.int/ $168007 d 004$

12. Рекомендащиия № Rec (2004) 10 Комитета министров Совета Европь государствам-иленам в отношении защить прав и достоинства лии, страдающих психическими расстройствами, и пояснительньй доклад (принята Комитетом министров 22.09.2004 на 896-м заседании заместителей министров). URL: https: / / rm.coe.int / rec-2004-10-psy-ru/168066caa8\#_ftn1.

13. Декларация о политике в области соблюдения прав пациента в Европе (Европейское совещание по правам пациента, Амстердам, Нидерланды, mapm 1994). URL: http://samlib.ru/s / stonogin_s_w/europe.shtml.
14. Конвенція про захист осіб у зв'язку з автоматизованою обробкою персональнuх даних (Страсбург, 28.01.1981). URL: conventions. coe.int/Treaty/en/Treaties / Word/108.doc.

15. Резолюиія Парламентської Асамблеї Ради Європи № 1165(1998). URL: http: / / cedem.org.ua/library/rezolyutsiya1165-1998-pravo-na-pryvatnist/.

16. Case of von Hannover v. Germany (Application no. 59320/00). URL: https: / / hudoc.e chr.coe.int/ tur\#\{\%22ite mid\% 22: [\% 22001-61853\%22]\}.

17. Сенюта I.Я. Лікарська таємниия в умовах COVID-19. URL: https:// medcom.unba.org.ua/publications/5362likars-ka-taemnicya-v-umovah-covid-19. html.

18. Беске Ф., Халлауер И. Здравоохранение Германии. Система - достижения - перспективы развития / пер. с нем. ; научн. ред. О.П. Щепина. Москва: Лaбnресс, 2000. 288 c.

19. Махник О.П. Из истории врачебной тайны. Hаучные труды II Bceроссийского съезда (Национального конгресса) по медииинскому праву, г. Москва, 13-15 апреля 2005 г. Москва : НАМП, 2005. С. 124-129.

20. Молдован В.В., Молдован А.В. Порівняльне-проиесуальне право: Україна, ФРН, Франція, Англія, США : навчальний посібник. Київ : Юринком Інтер, 1999. С. 289.

21. Dovhan A.D., Bernaziuk Y.O., Tkachuk T.Y. Internet of things technologies in medical sector: cybersecurity issues. Wiadomości Lekarskie. 2019. №12. P. 2563-2567. 